\title{
Morphology and taxonomy of chain forming species of the genus Cochlodinium (Dinophyceae)
}

\author{
Kazumi Matsuoka $^{\mathrm{a}}{ }^{*}$, Mitsunori Iwataki ${ }^{\mathrm{a}}$, Hisae Kawami ${ }^{\mathrm{b}}$
}

${ }^{a}$ Institute for East China Sea Research, Nagasaki University; 1551-7 Taira-machi, Nagasaki

851-2213, Japan (Laboratory; 1-14, Bunkyo-machi, Nagasaki, 852-8521, Japan)

${ }^{\mathrm{b}}$ Graduate School of Science and Technology, Nagasaki University, 1-14 Bunkyo-machi, Nagasaki 852-8521, Japan

* Corresponding author. Tel. \& fax: +81 958192812

E-mail address: kazu-mtk@nagasaki-u.ac.jp (K. Matsuoka)

Keywords: Cochlodinium polykrikoides, Cochlodinium heterolobatum, Cochlodinium catenatum, Cochlodinium convolutum, dinoflagellate, morphology, taxonomy, HAB 


\section{Introduction}

An unarmored chain-forming dinoflagellate Cochlodinium polykrikoides Margalef is one of the harmful species for fish aquaculture in western Japan and southern Korea in the last two decades. In Japan, this species was first recognized in the Yatsushiro Sound in 1978 with a serious economic damage to yellowtail aquaculture industries, and thereafter this species has been continuously expanding its habitat and giving damages to fish aquaculture in both Japan and Korea (Matsuoka and Iwataki, 2004). Recently, the geographical distribution of C. polykrikoides seems to expand apparently in tropical to subtropical coastal waters of the Philippines and Saba of Malaysia, Southeast Asia (Relox and Bajarias, 2003; Azanza and Baula, 2005; Anton, pers. com.). However, its biological nature such as taxonomy, the optimum environmental conditions for reproduction, life history including cyst formation and ichthyotoxicity is still unclear for the moment. In particular, reliable identification of $C$. polykrikoides is important among these unsolved subjects, because morphologically similar chain-forming species of the genus Cochlodinium have been reported around Japanese and Korean coastal waters (e.g. Yuki and Yoshimatsu, 1989). For investigating on occurrence of $C$. polykrikoides, the precise morphology of these similar species and prominent morphological features, which can differentiate C. polykrikoides from other similar species, should be clarified.

In this paper, we describe the morphology of $C$. polykrikoides and its similar species such as $C$. catenatum Okamura, C. convolutum Kofoid and Swezy, and C. fulvescens ., which is probably a new species, in focusing a single cell stage and discuss on taxonomic problems in the relation to $C$. polykrikoides. In addition, the occurrence locations of $C$. polykrikoides and its related species are shown based on the previous reports.

\section{Materials}

For observation on the morphology of a single cell and chain-forming cells of C. polykrikoides, the cultural cells collected from the following sites were provided; Imari Bay, Usuka Bay, Nama Bay, off Shikamachi, Tachibana Bay and Isahaya Bay of Nagasaki Prefecture, Inokushi Bay of Oita Prefecture, off Mishima of Yamaguchi Prefecture, west Japan, Manila Bay of the Philippines and Kota Kinabalu of Sabah, Malaysia. For morphological comparison to C. polykrikoides, another chain-forming species, C. fulvescens . similar to C. polykrikoides collected from Tachibana Bay, west Japan was also observed. To understand the morphological feature of $C$. catenatum, the original description and line drawings given by Okamura (1916) were also employed, because after the last occurrence of this species reported by Hirasaka (1922), C. catenatum has never been observed from Japanese coastal waters. For the description of $C$. fulvescens . the photomicrographs and description of this species given by Yuki and Yoshimatsu (1989) was also provided for the description of Cochlodinium sp. with our original data. Cells of another Cochlodinium species forming short cell-chains, C. convolutum, collected from Inokushi Bay, Oita Prefecture in November 2002 and Imari Bay, Nagasaki in September 2005, were also provided for morphological comparison. Information of specimens photographed in this paper is shown in Table 1. 


\section{Results}

\subsection{Cochlodinium polykrikoides Margalef (Fig. 1)}

Cochlodinium polykrikoides Margalef 1961, p. 76, 78, fig. 27m

\section{Synonyms:}

Cochlodinium heterolobatum Silva 1967

Cochlodinium sp. Type 78 of Kumada et al. 1980

Cochlodinium catenatum Okamura; Hargraves and Víquez 1981

\section{Description based on the Japanese-Korean populations:}

Single cell: Small (30-40 $\mu \mathrm{m}$ in length and 25-30 $\mu \mathrm{m}$ in width) and ovoidal. Anterior part of the epicone is widely conical, and the hypocone is subspherical (Fig. 1-A, B, C). The cingulum encircles twice of the cell and well concave. The sulcus closely runs down just below the cingulum (Fig. 1-A, B). A reddish orange pigmented body is located at the dorsal side of the epicone (Fig. 1-B). A spherical nucleus is large and positioned at the anterior of the epicone (Fig. 1-C, F). Chloroplasts are many, and rod-like shape and extending longitudinally (Fig. 1-B, D, E).

Chain forming cell: At the blooming time, C. polykrikoides easily makes chains consisting two, four, eight and sometimes sixteen cells. However, these chains usually contain morphologically different cells; the anterior cell having the flattened hypocone, the posterior cell possessing the truncated epicone and lobed antapical end, and the intermediate cells being more or less compressed longitudinally (Fig. 1-F). However, other features such as the position of the sulcus, nucleus, and a single reddish orange pigmented body and are the same of the single cell stage.

\section{Geographical distribution:}

Type locality; Phosphorescence Bay, Puerto Rico, Atlantic Ocean (Margalef, 1961).

Western Pacific Ocean: Sea of Japan in Eastern Russia?? (Orlova et al., 2004; questionable because of only record of cyst in sediment), several places in West Japan (Matsuoka and Iwataki, 2004), Southern Coast of Korean Peninsula (Kim, 1998), Manila Bay, Iligan Bay, Balayan Bay and Puerto Princesa of the Philippines (Relox and Bajarias, 2003; Azanza and Baula, 2005), Sabah of Malaysia (Azanza et al., 2006; Anton, pers. com.), Hong Kong (Lu and Hodgkiss, 1999).

Eastern Pacific Ocean: Pacific coast of Guatemala (Rosales-Loessener et al., 1996), Southern California, U.S.A. (Kudela, 2006), Central California U.S.A. (M. Silver in Kudela, 2006), the Gulf of Nicoya, Costa Rica (Vargas-Montero et al., 2004), La Ense-nada de La Paz of Baja California (Gárate-Lizárraga et al., 2000, 2004), Manzanillo Bay, Colima, Mexico (Morales-Blake et al., 2001) , Pacific coast of Guatemala (Rosales-Loessener et al., 1996).

Atlantic Ocean: Coast of New Jersey, USA (as C. heterolobatum by Silva 1967), York River, Virginia, (as C. heterolobatum by Ho and Zubkoff, 1979), Peconic Estuary, Long Island, New York in U.S.A (Nuzzi, 2004; Kudela, 2006).

Mediterranean Sea: Coast of Naples, Italy (Zingone et al., 2006).

Indian Ocean: Goa, Southwest India (Bhat and Matondkar, 2004). 


\section{Remarks:}

The holotype of C. polykrikopides was ca. $50 \mu \mathrm{m}$ in cell length, collected from Puerto Rico and specimens of Malaysian Sabah however, specimens of C. polykrikoides occurring in Japanese and Korean coastal waters is significantly smaller $(30-40 \mu \mathrm{m})$ than the type specimens. The smaller $C$. polykrikoides has bee also reported from Gulf of California (Gárate-Lizárraga et al., 2004) and Gulf of Nicoya (Hargraves and Viquez 1981).

\subsection{Cochlodinium catenatum Okamura (Fig. 2)}

Cochlodinium catenatum Okamura 1916, p. 41, figs 1-3; Hargraves and Víquez 1981, p. 33, fig. 1. Synonym: Pouchetia sp. of Nakazawa 1911, p. 304, fig. 4.

Non: Cochlodinium catenatum Okamura sensu Kofoid and Swezy (1921) from off La Jolla, California

\section{Description:}

This species was first described from plankton samples collected from Yokohama Harbor in Tokyo Bay by Okamura (1916). The following morphological features of C. catenatum are based on the drawings of the holotype using camera lucida and description given by Okamura (1916; Figs 1-3, and p. 41)

Organism is small (21-26 $\mu \mathrm{m}$ in length and 21-27 $\mu \mathrm{m}$ in width in chain-forming cells), catenate and unarmored species usually composed of four eight, or sixteen cells, which are weakly combined. Cell is sub-spherical to ovoidal with almost equal size of the epicone and the hypocone (Fig. 2-A, C). The cingulum located at the equator is approximately one-sixth of the cell length in width, and is descending levorotary with more than 1.5 turns. The sulcus is not extending into the epicone and making almost a half turn (Fig. 2-B). The large nucleus is located at the apex and occupies almost half of the cell (Fig. 2-A, C). A small reddish orange pigmented body, which was called as a stigma by Okamura (1916) located in the epicone (Fig. 2-B). Many yellowish-brown chloroplasts are rod-like in shape and extend antero-posteriorly (Fig. 2-A). No information on the apical groove for the moment.

The cell shape of this species is mostly subspherical, however, some cells shown in the original drawings such as the anterior and posterior cells of fig. 2 and the posterior cell of fig. 3 of Okamura (1916) seem to be rather ovoidal to shortly ellipsoidal in shape (Fig. 2-B and A, respectively). However, no single cell was illustrated in the original drawings.

\section{Geographical distribution:}

Type locality; Yokohama Harbor in Tokyo Bay, Pacific Ocean (Okamura, 1916; Nakazawa, 1911 only illustration)

Western pacific: Mikawa Bay and Gokasho Bay of Central Japan (Hirasaka, 1922)

East Pacific Ocean; Mazatlan Bay, Mexico (Altamirano et al., 2004), Nicoya Bay of Costa Rica (Hargraves and Víquez, 1981), Nicoya Bay of Costa Rica and Panama (Guzman et al., 1990)

\subsection{Cochlodinium fulvescens Iwataki, Kawami and Matsuoka(Fig. 3)}


Cochlodinium fulvescens Iwataki, Kawami and Matsuoka 2007, p.235, Figs. 1-9.

Synonym: Cochlodinium sp. of Yuki and Yoshimatsu 1989

\section{Description:}

C. fulvescens . collected from Tachibana Bay, west Japan, and Hurun Bay in south Sumatra of Indonesia is also making a chain consisting of two or four cells. Due to the formation of cell chains, this species is apparently similar to C. polykrikoides. Its morphological features are followings.

A single cell: Relatively large, 45-50 $\mu \mathrm{m}$ in length and 30-35 $\mu \mathrm{m}$ in width. Cell is more roundly and ellipsoidal in shape (Fig. 3-C). The cingulum also encircles twice of the cell as well as that of $C$. polykrikoides. Sulcus runs down apart from the cingulum and occupies at the intermediate position between the semicircular cingulum at the dorsal side (Fig. 3-A, B). A reddish orange pigmented body is located at the dorsal side of the epicone (Fig. 3-B, E). A nucleus is spherical and located at the anterior part of the epicone (Fig. 3-C, F). Chloroplasts are granular and probably distributed along the cingulum and the periphery of the cell (Fig. 3-D). No information on the apical groove.

Chain forming cells: This species usually appear as two, rarely four cells chain (Fig. 3-E, F, G). However, these chain-forming cells easily separate. In the two-cells form, a boundary of these cells becomes mostly linear (Fig. 3-F), and in the four-cells form, the two cells of the anterior and posterior parts of the intermediate two cells are truncated at the both anterior and posterior ends as the same as C. polykrikoides (Fig. 3-G).

Cochlodinium sp. described by Yuki and Yoshimatsu (1989, p. 452, fig. 2) is identical to $C$. fulvescens . of the present article judging from the lager cell size, the position of the sulcus and granular chloroplasts. According to Yuki and Yoshimatsu (1989), Cochlodinium sp. occurred in Harima-Nada, Seto Inland Sea in west Japan with a small-scaled red tide and showed ichtyotoxicity to juveniles of Leiognotus nuchalis. For the moment, the physiological condition such as the optimum growth condition has not examined yet, however, the geographical distribution suggests that this species is probably a warm temperate to tropical species as well as C. polykrikoides.

\section{Geographical distribution:}

Tachibana Bay of West Kyushu, Seto Inland Sea (Yuki and Yoshimatsu, 1989) of west Japan Hurun Bay, South Sumatra of Indonesia (Fig. 5).

\subsection{Cochlodinium convolutum Kofoid and Swezy 1921 (Fig. 4)}

Cochlodinium convolutum Kofoid and Swezy 1921, p. 363, pl. 10, fig. 115.

\section{Description:}

Cell is elongated ovoidal to roundly fusiform in shape and ca. 60-70 $\mu \mathrm{m}$ in length and 30-45 $\mu \mathrm{m}$ in width (Fig. 4-A). The epicone becomes slender toward the apex, and the hypocone is rounder with two broad lobes; the left being always larger than the right (Fig. 4-B). An orange pigmented body developed in C. polykrikoides is absent. Torsion of the cingulum is approximately 1.5 times (Fig. 4-A). The sulcus is deep and extends into the hypocone, and also immediately apart at the crossing part of the cingulum. A nucleus is roundly rectangular in shape and located in the center 
and at the left ventral side of the cell (Fig. 4-B). The chloroplast is reticulate, but sometimes fairly (Fig. 4-C). Many small grains are evenly scattered in the periphery (Fig. 4-D). A hyaline membrane is often formed around the cell (hyaline cyst) (Fig. 4-E). Two-cell chains are rarely observed in natural condition (Fig. 4-F), but mainly appeared as a single cell.

Cochlodinium convolutum once made a red tide in the most inner part of Kagoshima Bay, west Japan in September 1997 (Wada pers. com.), and thereafter appeared in Yatsushiro Sound in September 2001. Recently this organism was recorded from Inokushi Bay, Oita Prefecture of west Japan in November 2002, Omura Bay and Imari Bay in Nagasaki Prefecture of west Japan. When this species occurred in Japan, the temperature of surface water was $26-27^{\circ} \mathrm{C}$, and salinity was $32-33$ psu. Kofoid and Swezy (1921) reported the occurrence of C. convolutum on July and August 1914 from off La Jolla of the west coast of U.S.A. and the surface temperature was $20.7-21.0^{\circ} \mathrm{C}$. These data show that $C$. convolutum is the warm temperate to tropical species. This species caused neither fish nor shellfish mass mortality in the field where the red tide occurred and in the laboratory experiments that exposed C. convolutum of $2.8-2.0 \times 10^{3}$ cells $/ \mathrm{ml}$ to yellow tails (Wada, pers. com.). According to these observations, $C$. convolutum is a red-tide forming species, but less harmful for fish and shellfish for the moment.

\section{Geographical distribution:}

Off La Jolla of the west coast of U.S.A. (Kofoid and Swezy, 1921).

Kagoshima Bay, Omura Bay, Yatsushiro Sound, Imari Bay and Ariake Sound of West Japan.

\section{Discussions}

\subsection{Cochlodinium polykrikoides Margalef vs. Cochlodinium catenatum Okamura}

Cochlodinium polykrikoides was established in 1961 by Margalef based on the plankton material collected from Phosphorescent Bay in Puerto Rico, Caribbean Sea. In Japan, C. catenatum was first reported as a new species by Okamura in 1916 from Tokyo Bay before C. polykrikoides being described. Unfortunately, Margalef (1961) did not make any morphological comparison between $C$. catenatum and $C$. polykrikoides, nevertheless these two species share several important morphological and ecological features such as naked, chain-forming, causative for red-tides and ichthyotoxic characteristics. The cell shape of $C$. polykrikoides is slightly different from that of $C$. catenatum in being rather ellipsoidal. However, both species have a small reddish orange pigmented body and many rod-like and yellowish-brown chloroplasts longitudinally distributed near the cell surface. In addition, the position of the nucleus located at the anterior part of the epicone is also common in both species. (Table 2)

According to Okamura (1916), the ichnotype of C. catenatum was illustrated using a camera lucida. If Okamura (1916) started to sketch the type specimens of $C$. catenatum, these specimens might stop swimming. Unfortunately, when unarmored dinoflagellates like C. polykrikoides stop moving, outlines of these motile cells are easily deformed time by time. The similar cell deformation in C. heterolobatum has been shown by Silva (1967, pl. 1, figs 5-7). Actually during our observation on vegetative cells of $C$. polykrikoides, we also encountered these morphological changes (Fig. 6).

The type locality of $C$. catenatum is Tokyo Bay in, Japan, but after the original report given by Okamura (1916), this species has never been observed in this bay. Subsequently in 1922 Hirasaka 
reported the occurrence of this species from Gokasho Bay facing to the Pacific in west Japan, and this is the last record of C. catenatum in Japan. More than fifty years later, C. polykrikoides was found in Gokasho Bay in 1983 (Yuki, pers. com.). Thus these two species can share several important morphological and ecological features.

In the eastern side of the Pacific, these two chain-forming Cochlodinium species have been reported by different authors for the moment (Table 3). Hargraves and Víquez (1981) examined a photosynthetic, non-thecate dinoflagellates occurring with fish mass mortality in Nicoya Bay of Costa Rica and identified this species as $C$. catenatum after careful observation and comparison with C. polykrikoides and C. heterolobatum. In the examination of phytoplankton species of harmful algae forming blooms in Mazatlan Bay in Mexico. Altamirano et al. (2004) reported C. catenatum as one of HAB causative species, but neither morphological description nor photographs of this species were given. On the other hand, Vargas-Montero et al. (2004) reported extensive blooms caused by a chain-forming species identical to C. polykrikoides, which newly occurred in the same bay, Nicoya Bay. However, based on their LM and SEM photographs (Vargas-Montero et al., 2004, figs 1, 2), the organisms seem to have very similar morphological characters of the species shown by Hargraves and Víquez (1981, fig. 1). This case shows that from the same Nicoya Bay, two different Cochlodinium species, C. catenatum and C. polykrikoides have been identified by different authors. These observations and reports strongly suggest that $C$. polykrikoides is probably a synonym of $C$. catenatum.

For getting the clear taxonomic conclusion on these two species, molecular phylogenetic examination should be carried out on morphologically identical organisms to C. catenatum sensu Okamura should be collected from the type locality. Unfortunately, it is almost impossible to find out C. catenatum in present Tokyo Bay, because the water quality of this bay has been changed drastically to eutrophic condition since 1916 when C. catenatum occurred. However, instead of this situation, from Gokasho Bay facing to the Pacific in central Japan where is an upper stream region of Kuroshio Current, both C. catenatum sensu Okamura and C. polykrikoides were observed by different authors in different times, in 1922 by Hirasaka and in 1983 by Yuki (pers. com.), respectively. Therefore, for molecular phylogenetic examination, specimens collected from Gokasho Bay will be useful in future.

\subsection{Cochlodinium catenatum Okamura vs. Cochlodinium catenatum Okamura sensu Kofoid and Swezy 1921}

After the original description of C. catenatum given by Okamura (1916), Kofoid and Swezy (1921) also described this species from off La Jolla, California. However, Hirasaka (1922) pointed out that C. catenatum reported by Kofoid and Swezy (1921) was not identical to C. catenatum sensu Okamura in having no chloroplast, no reddish orange pigmented body, and the nucleus located at the center of the cell (Fig. 7). Thereafter, during the study on red-tides caused by a catenate dinoflagellate in Nicoya Bay of Costa Rica, as above mentioned Hargraves and Víquez (1981) identified this species as C. catenatum once again. Hargraves and Víquez (1981) also suggested this unarmored dinoflagellate not to be identical to C. catenatum sensu Kofoid and Swezy as well as Hirasaka (1922), and probably identical to C. catenatum sensu Okamura (1916). On the other hand, Rosales-Loessener et al. (1996) reported the dense bloom caused by C. polykrikoides from coastal waters of the Pacific side of Guatemala. These observations also support that $C$. catenatum may be 
the senior synonym of C. polykrikoides (Table 3).

\subsection{Cochlodinium polykrikoides Margalef vs. Cochlodinium heterolobatum Silva}

Cochlodinium heterolobatum was first described from the coast of New Jersey, U.S.A. by Silva in 1967. Again unfortunately, Silva (1967) did not examine morphological comparisons between $C$. polykrikoides and $C$. heterolobatum, and did not discuss the differences between two species. According to the original description and the holotype of $C$. heterolobatum, this species is characterized by a cannonball shape in the single cell stage, with many chloroplasts rod-like shaped, an orange spot (= reddish orange pigmented body) positioned in the epicone, and a large nucleus located at the anterior part of the epicone. This species also makes chain usually consisting of four cells. Later, Hargraves and Víquez (1981) discussed the morphological differences among chain-forming species of Cochlodinium including the material collected from Nicoya Bay, and suggested that there is no remarkable morphological difference among C. polykrikoides, $C$. heterolobatum and Nicoya Bay specimens. Thereafter, Yuki and Yoshimatsu (1989) re-examined Japanese Cochlodinium sp. type 78-Yatsushiro, and concluded that Cochlodinium sp. type 78-Yatsushiro is attributable to $C$. polykrikoides and $C$. heterolobatum is a junior synonym of $C$. polykrikoides (Table 2, 3).

\section{Conclusions}

1. Two ichthyotoxic chain-forming Cochlodinium species, C. polykrikoides and C. fulvescens . are inhabiting in the coasts of west Japan and southern Korea, and the East China Sea, and their distribution is expanding toward the south.

2. Morphological features of three species, C. polykrikoides, C. convolutum and C. fulvescens . at the single cell stage are similar to each other, however, the cell size, the position of the nucleus and the sulcus, and shape of chloroplasts are clearly different among them.

3. Cochlodinium catenatum Okamura reported from off La Jolla, U.S.A. by Kofoid and Swezy in 1921 is a different species of C. catenatum sensu Okamura in lacking chloroplasts, and the nucleus located at the center of the cell.

4. The type specimen of Cochlodinium polykrikoides Margalef is significantly larger than the C. polykrikoides of Japanese-Korean populations in cell length.

5. Cochlodinium polykrikoides Margalef distributing along the Japanese and Korean coasts is possibly the same species of $C$. catenatum Okamura in having many yellowish-brown chloroplasts with rod-like shape, making a chain consisting of more than four cells, the nucleus located at the anterior part of the epicone, excepting only ellipsoidal body. However, the adequate taxonomic name for these species should be re-examined based on morphological and molecular phylogenetic data using the topotype of $C$. catenatum.

\section{Acknowledgements}


Thanks for kind co-operation to collect samples and information of Cochlodinium polykrikoides for different areas in west Japan and Southeast Asia to Dr. T. Yamatogi, Mr. K. Miyamura, Mr. T. Baba, Mr. M. Wada, Mr. K. Yuki, Mr. J.R. Relox Jr. and late Ms. F.F.A. Bajarias of BFAR of the Philippines and Dr. A. Anton of the University of Malaysia, Sabah.

\section{References}

Altamirano, R.C., Sierra-Beltran, A.P., Carmen Cortes Lara, M. 2004 Dominance and Permanence of species of harmful algae forming blooms in Mazatlan Bay, Mexico (1979-2002). In: Steidinger, K.A., Landsberg, J.H., Tomas, C.R. and Vargo, G.A. (eds.) Harmful Algae 2002, Florida Fish Wildlf. Conserv. Comm., Florida Inst. Oceanog. IOC of UNESCO, pp. 344-346.

Azanza, R.V., Baula, I.U., 2005. Fish kills associated with Cochlodinium blooms in Palawan, the "last frontier" of the Philippines. Harmful Algae News 29, 13-14.

Azanza, R.V., David, L.T., Borja, R.Y., Fukuyo, Y., 2006. Cochlodinium blooms in the Philippines and neighboring countries in Southeast Asia. In: Proceedings of Workshop of recent progress on the research and management of Cochlodinium blooms, MOMAF-NFRDI and NOAA, Cheju Korea, pp. 27-33.

Bhat, S.R., Matondkar, S.G.P., 2004. Algal blooms in the seas around India - networking for research and outreach. Current Sci. 87, 1079-1083.

Cheong, L., Chuan, L.L., Chung, C.Y., 1984. Status of shellfish toxicity in Singapore. In: White, A.W., Anraku, M., Hooi, K.K. (Eds.), Toxic Red tide and shellfish toxicity in Southeast Asia. SEAFDEC, Singapore and international Development Center, Ottawa, p. 86.

Gárate-Lizárraga, I., Bustillos-Guzmán J.J., Morquecho, L., Lechuga-Déveze, C., 2000. First outbreak of Cochlodinium polykrikoides in the Gulf of California. Harmful Algae News 21. 7.

Gárate-Lizárraga, I., López-Cortes, D.J., Bustillos-Guzmán, J.J., Hernández-Sandoval, F., 2004. Blooms of Cochlodinium polykrikoides (Gymnodiniaceae) in the Gulf of California, Mexico. Rev. Biol. Trop. 52 (Suppl. 1), 51-58.

Guzman, H.M., Cortes, J., Glynn, P., Richmond, R.H., 1990. Coral mortality associated with dinoflagellate blooms in the eastern Pacific (Costa Rica and Panama). Mar. Ecol. Prog. Ser. 60, 299-203.

Hargraves, P.E., Víquez, R., 1981. The dinoflagellate red tide in Golfo Nicoya, Costa Rica. Rev. Biol. Trop. 29, 31-38.

Hirasaka, K., 1922. Red tides appeared in this spring (Honnen Shunki ni Okoreru Akashio). Zool. Mag. 34, 740-748. (in Japanese).

Ho, M.-S., Zubkoff, P.L., 1979. The effects of a Cochlodinium heterolobatum bloom on the survival and calcium uptake by larvae of the American oyster, Crassostrea virginica. In: Taylor, D.L., Seliger, H.H. (Eds.) Toxic dinoflagellate blooms, Elsevier/North-Holland, pp. 409-412.

Iwataki, M., Kawami, H., Matsuoka K. 2006. Cochlodinium fulvescens sp. nov. (Gymnodiniales, Dinophyceae), a new chain-forming unarmored dinoflagellate from Asian coasts. Phycol. Res. 55, 231-239

Kim, H.-G. 1998. Harmful algal blooms in Korean coastal waters focused on three-fish-killing dinoflagellates. In: Kim, H.-G., Lee, S.-G., Lee, C.-K. (Eds.), Harmful Algal Blooms in Korea 
and China. NFRDI, Pusan, pp. 1-20.

Kim, C.-H., Cho, H.-J., Shin, J.-B., Moon, C.-H., Matsuoka, K., 2002. Overwintering potential of hyaline cysts of Cochlodinium polykrikoides (Gymnodiniales, Dinophyceae): An annual red tide organism along the Korean coast. Phycologia 41, 667-669.

Kofoid, C.A., 1931. Report of the biological survey of Mutsu Bay. 18. Protozoan Fauna of Mutsu Bay. Subclass Dinoflagellata; Tribe Gymnodinioidae. Sci. Rep. Tohoku Imperial Univ., Fourth Ser. (Biol.) 6, 1-43.

Kofoid, C.A., Swezy, O., 1921. The free living unarmored Dinoflagellata. Memoirs Univ. California (Berkeley) 5, 1-564.

Kudela, R.M., 2006. Linking the physiology and ecology of the harmful red tide organism Cochlodinium to better understand bloom events. In: Proceedings of Workshop of recent progress on the research and management of Cochlodinium blooms, MOMAF-NFRDI and NOAA, Cheju, pp. 51-56.

Kumada, K., Takeda, K., Aramaki, T., 1980. Yatsushiro Kaiiki, Tatsushiro Kai-2. In: Fisheries Agency, Fukuokaken Suisan Shikenjou, Sagaken Suisan Shikenjou, Nagasakiken Suisan Shikenjou, Kumamotoken Suisan Shikenjou, Kagoshimaken Suisan Shikenjou (Eds.), Kyushu Seikaiiki Akashio Yosatsu Chosa Hokokusho, pp. 125-136.

Lu, S., Hodgkiss, I.J., 1999. An unusual year for the occurrence of harmful algae. Harmful Algae News 18, 1-3.

Margalef, R., 1961. Hidrografia y fitoplancton de un área marina de la costa meridional de Puerto Rico. Invest. Pesq. 18, 33-96.

Matsuoka, K., Iwataki, M., 2004. Present status in study on a harmful algal unarmored Cochlodinium polykrikoides Margalef. Bull. Plankton Soc. Jpn. 51, 38-45. (in Japanese)

Morales-Blake, A., Cavazos-Guerra, C., Hernández-Becerril, D., 2001. Unusual HABs in Manzanillo Bay, Colima, Mexico. Harmful Algae News 22, 6.

Nakazawa, K., 1911. On the red-tide (Akashio ni Tsuite). Zool. Mag. (Dobutsugaku Zasshi) 272, 304-306. (in Japanese).

Nuzzi, R., 2004. Cochlodinium polykrikoides in the Peconic Estuary. Harmful Algae News 27, $10-11$.

Okamura, K., 1916. Akashio ni Tsuite (On red-tides). Suisan Koushu Sikenjo Kenkyu Hokoku 12, 26-41. (in Japanese).

Orlova, T.U., Morozova, T.V., Gribble, K.E., Lulis, D.M., Anderson, D.M., 2004. Dinoflagellate cysts in recent marine sediments from the east coast Russia. Bot. Mar. 47, 184-201.

Relox Jr., J.R., Bajarias, F.F.A., 2003. Harmful algal booms (HABs) in the Philippines. In: Furuya, K. Fukuyo, Y. (Eds.), Extended abstracts of Workshop on Red Tide Monitoring in Asian Coastal Waters. March 10-12, 2003, the University of Tokyo, Tokyo, pp. 65-68.

Rosales-Loessener, F., Matsuoka, K., Fukuyo, Y., Sanchez, E.H., 1996. Cysts of harmful dinoflagellates found from Pacific coastal waters of Guatemala. In: Yasumoto, T., Oshima, Y., Fukuyo, Y. (Eds.), Harmful and Toxic Algal Blooms. IOC-UNESCO, Sendai, pp. 193-195.

Silva, S.E., 1967. Cochlodinium heterolobatum n. sp.: Structure and some cytophysiological aspects. J. Protozool. 14, 745-754.

Vargas-Montero, M., Freer, E., Jiménez-Montealegre, R., Guzmán, J.C., 2004. Extensive blooms due to Cochlodinium polykrikoides: new to Costa Rica. Harmful Algae News 26, 7. 
Yamatogi, T., Maruta, H., Ura, K., 2003. Occurrence of Cochlodinium polykrikoides red tide and its growth characteristics in Imari Bay in 1999. Bull. Nagasaki Pref. Inst. Fish. 28, 21-26. (in Japanese).

Yuki, K., Yoshimatsu, S., 1989. Two fish-killing species of Cochlodinium from Harimanada, Seto Inland Sea, Japan. In: Okaichi, T., Anderson, D.M. Nemoto, T. (Eds.), Red Tides; Biology, Environmental Science and Toxicology. Elsevier, New York, pp. 451-454.

Zingone, A., Siano, R., D’Alelio, D., Sarno, D., 2006. Potentially toxic and harmful microalgae from coastal waters of the Campania region (Tyrrhenian Sea, Mediterranean Sea). Harmful Algae 5, 321-337. 


\section{Abstract}

Morphology of an unarmored chain-forming harmful dinoflagellate Cochlodinium polykrikoides and its similar species such as C. catenatum, C. fulvescens, and C. convolutum was carefully observed in focusing a single cell stage for clarifying taxonomically important morphological features. To differentiate $C$. polykrikoides from $C$. convolutum, the shape and the position of the nucleus are useful characters. C. polykrikoides is also different from C. fulvescens in being smaller in size, having many rod-like chloroplasts and the sulcus running just below the cingulum on the dorsal surface. Careful observation on the ichnotype of $C$. catenatum suggests that $C$. catenatum sensu Kofoid and Swezy collected from off La Jolla is not identical to C. catenatum sensu Okamura and probably a different species in having no chloroplast and a nucleus positioned at the center of the cell. In addition, C. polykrikoides has many common morphological features with $C$. catenatum sensu Okamura only except for slightly elongate cells and is probably a junior synonym of this species. 


\section{Explanation of Figures}

Fig. 1. Light and fluorescent micrographs of Cochlodinium polykrikoides. (A) Ventral view; (B) Dorsal view showing the position of the sulcus (s), chloroplasts (ch) and reddish orange pigmented body (arrowhead); (C) Optical cross section showing the nucleus (n) positioned in the anterior of the cell; (D) Fluorescent micrograph, showing rod-like chloroplasts; (E) A four cells chain showing different cell morphology in cell-chain; (F) Deeper focus of a cell chain indicates the positions of nuclei. Scale bars: $10 \mu \mathrm{m}$.

Fig. 2. Cochlodinium catenatum Okamura. A-C are the same of figs. 3-1 of Okamura 1916, but abbreviations are changed from the original, cingulum (c), chloroplasts (ch), nucleus (n), sulcus (s), arrowheads; reddish orange pigmented body.

Fig. 3. Light and fluorescent micrographs of $C$. fulvescens . (A) Ventral view showing the start of the sulcus (s); (B) Dorsal view showing reddish orange pigmented body (arrowhead) and the position of the sulcus (s); (C) Optical cross section in dorso-ventral view showing the nucleus (n); (D) Fluorescent micrograph, showing granular chloroplasts peripherally located; (E, F) A chain-form consisting of two cells; (G) A chain-form consisting of four cells. Scale bars: 20 $\mu \mathrm{m}$.

Fig. 4. Light and fluorescent micrographs of Cochlodinium convolutum.(A) Ventral view showing the sulcus (s); (B) Optical cross section showing rectangular nucleus (n); (C) Fluorescent micrographs, showing reticulate chloroplasts; (D) Right lateral view, many small grains evenly scattered in the cell; (E) Optical cross section, showing the hyaline membrane (arrowhead); (F) A chain-form consisting of two cells. Scale bars: $20 \mu \mathrm{m}$.

Fig. 5. Geographical distribution of Cochlodinium polykrikoides, C. catenatum and C. fulvescens . Temperatures in summer season.

Fig. 6. Morphological change of Cochlodinium polykrikoides during the observation under a light microscope. Specimens collected at Busan, Korea in August 2002. (A) Cells stopping to swim and becoming round in outline of cells and chloroplasts; (B) Cells remarkably deformed and original rod-like chloroplasts decomposed after approximately two hours from microscopic observation. Scale bar: $20 \mu \mathrm{m}$

Fig. 7. The different type of C. catenatum given by Kofoid and Swezy (1921): (A, B) Re-drawings of Kofoid and Swezy in 1921. Showing the position of nucleus (n), note the cell of $C$. catenatum sensu Kofoid and Swezy having no chloroplast.

Table 1. Chain-forming Cochlodinium species examined in this study.

Table 2. Taxonomic history of chain-forming species of the genus Cochlodinium. 
Table 3. Morphological comparison of a single cell stage of four Cochlodinium species occurring around Japanese coastal waters. 

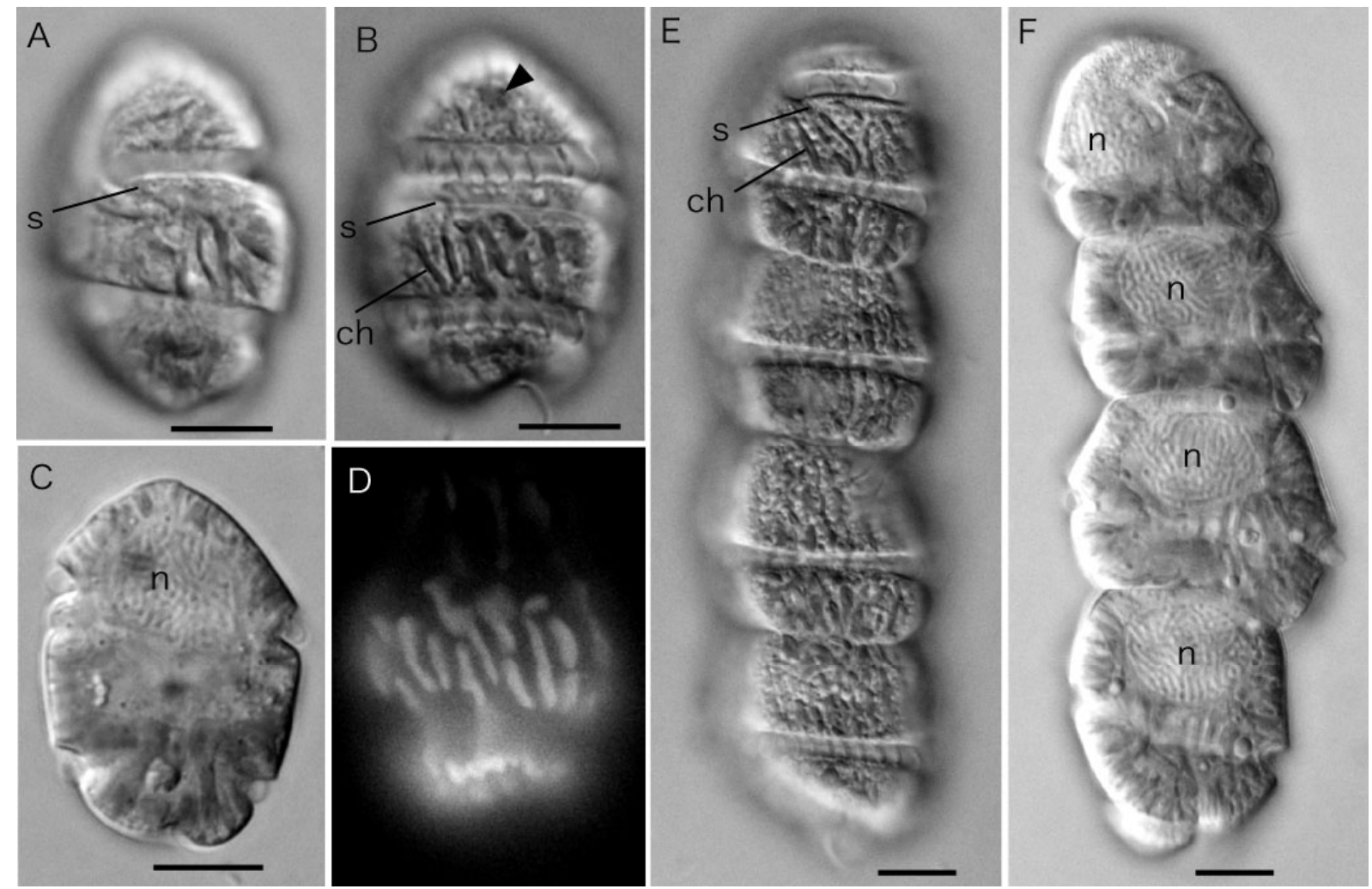

Fig. 1

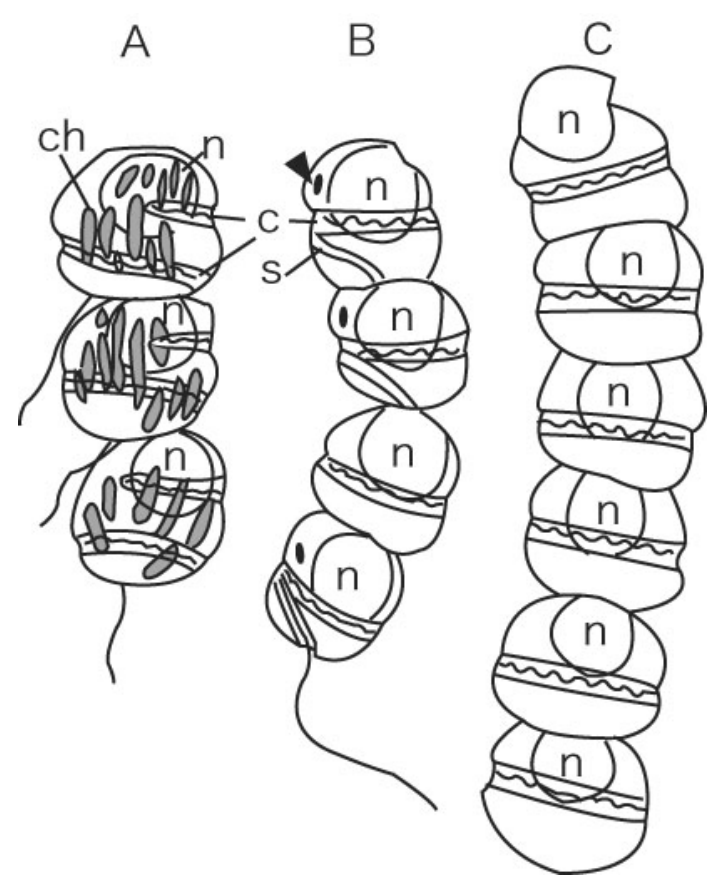

Fig. 2 

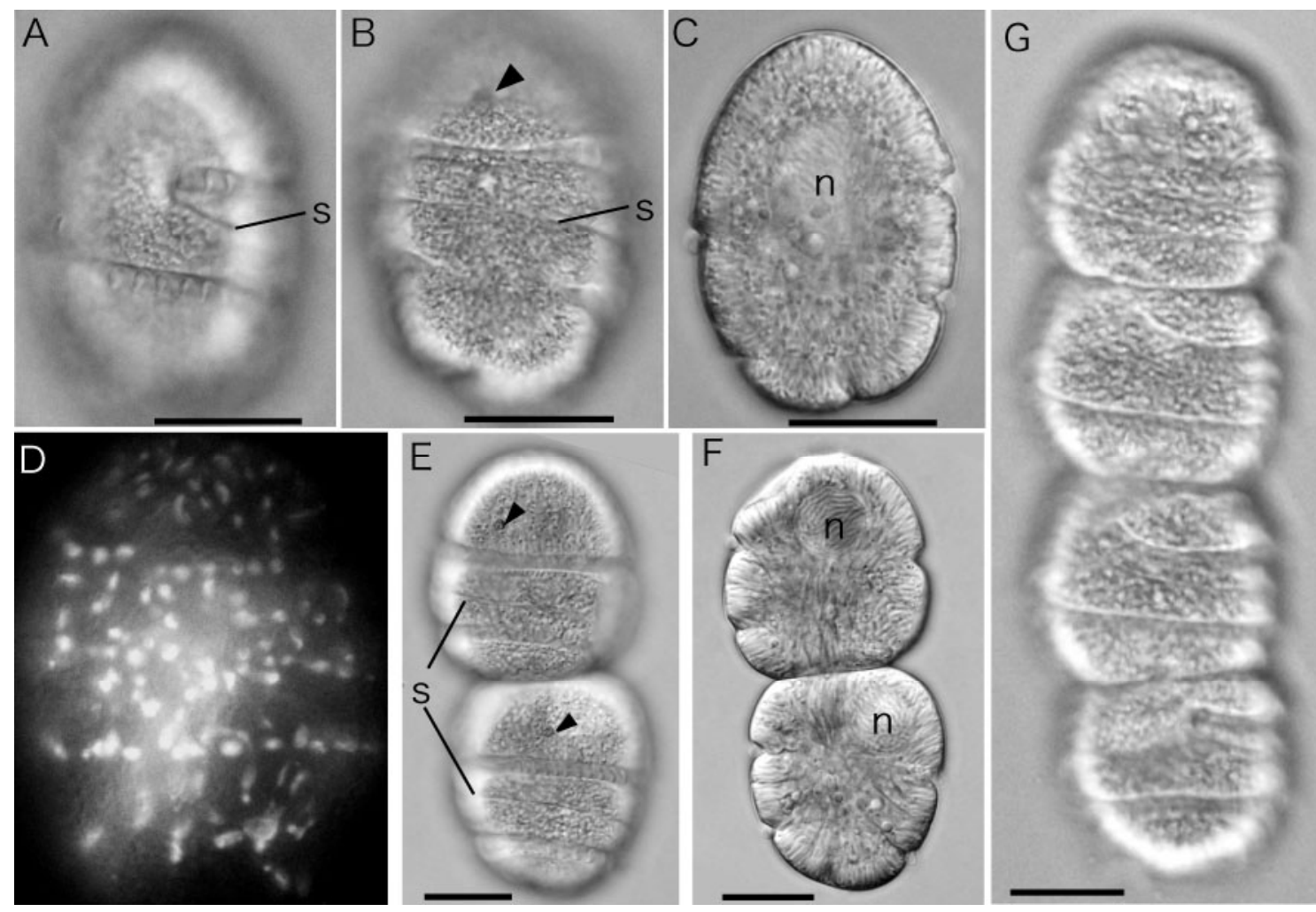

moxt

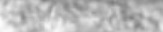

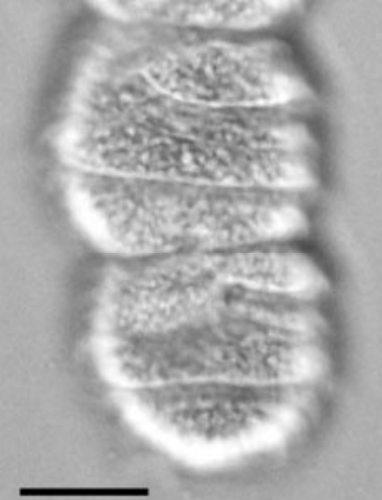

Fig. 3 

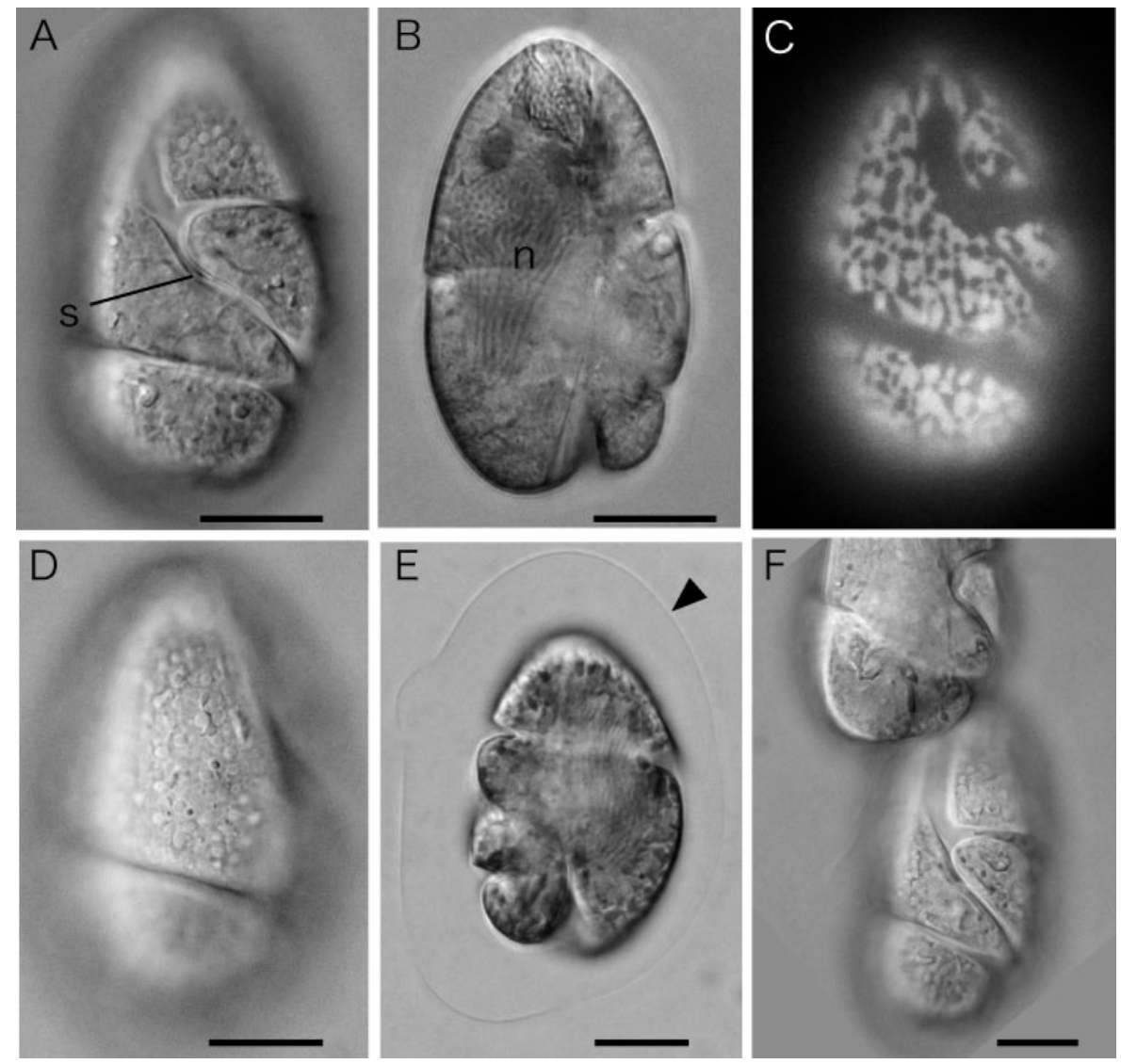

Fig. 4

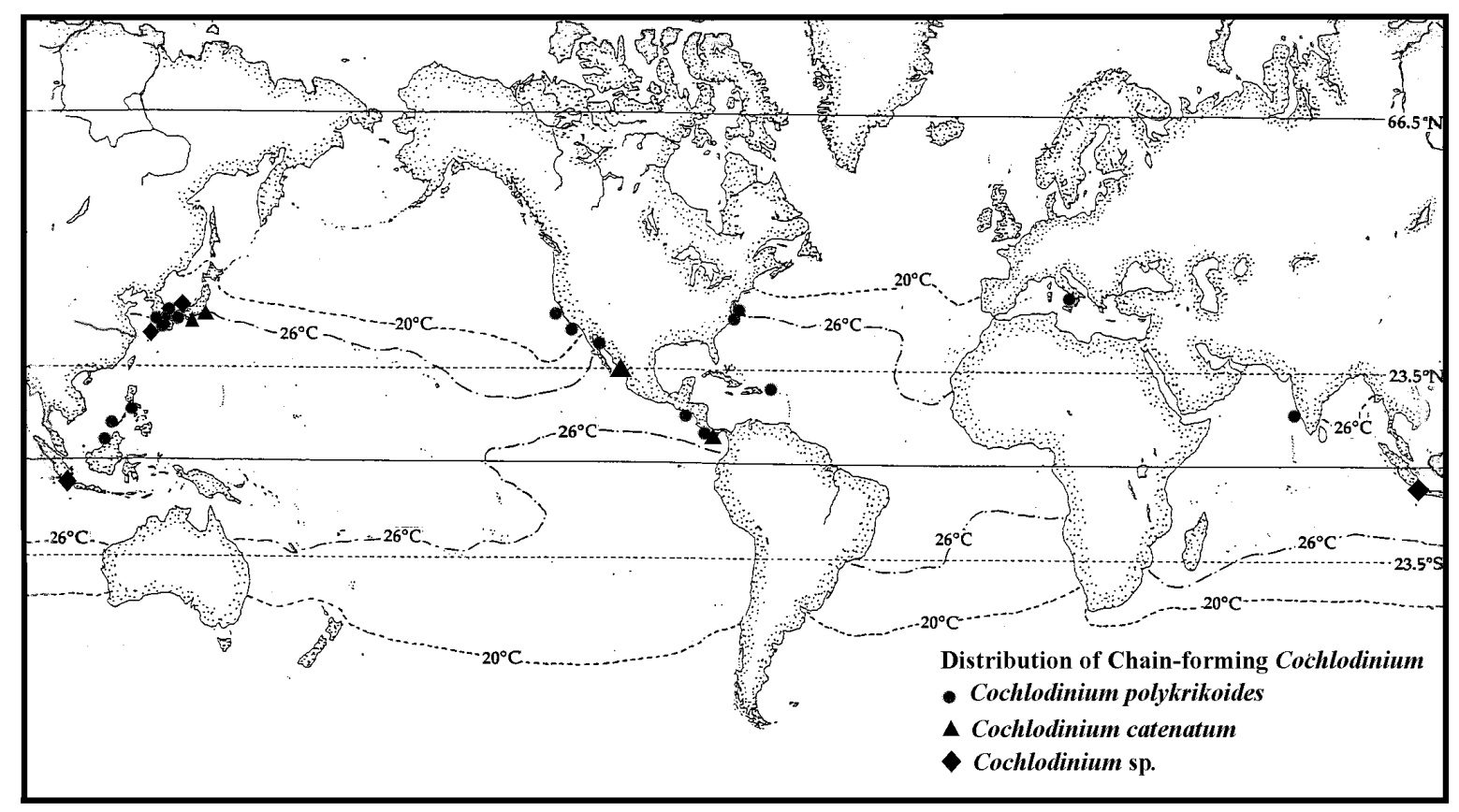

Fig. 5 


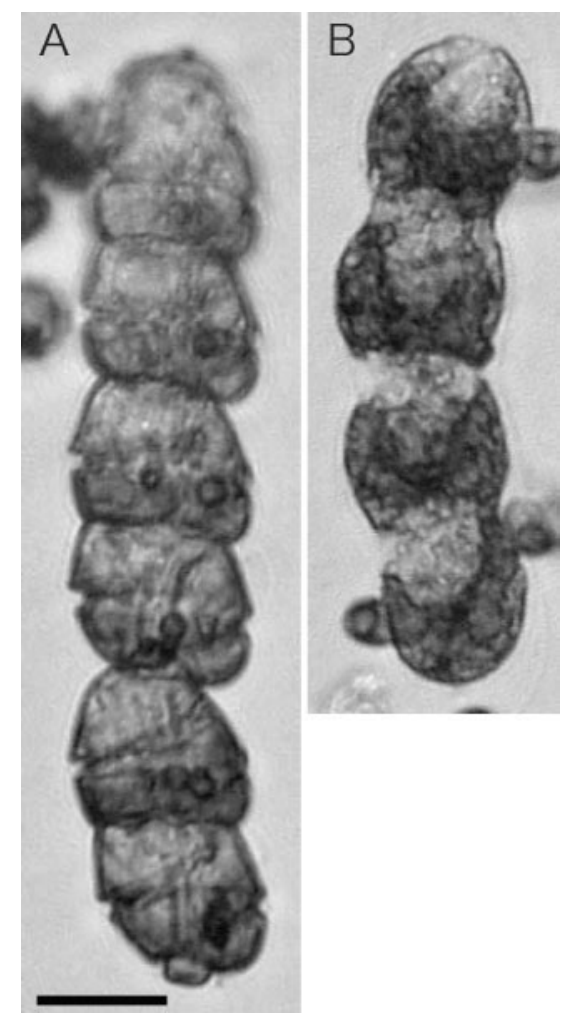

Fig. 6

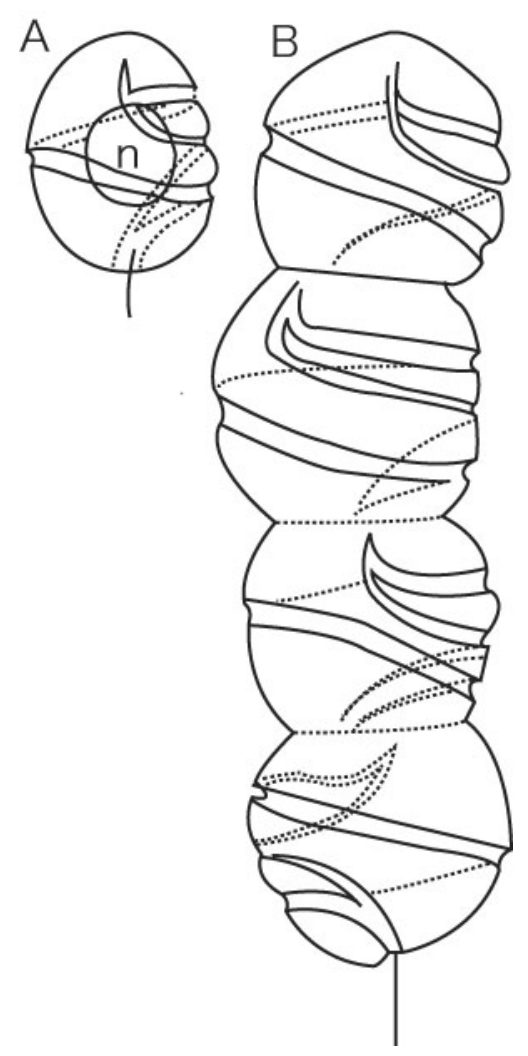

Fig. 7 
Table 1. Chain-forming Cochlodinium species examined in this study.

\begin{tabular}{|c|c|c|c|c|}
\hline Species & Strain & Location & Date & Photographs \\
\hline $\begin{array}{l}\text { Cochlodinium } \\
\text { polykrikoides }\end{array}$ & KG8-ND14 & Nama Bay, West Japan & 27 Aug 2002 & Fig. 1, A-F \\
\hline C. fulvescens. & TC10-ND102 & Tachibana Bay, West Japan & 17 Oct 2004 & Fig. 2, A-D, G \\
\hline C. fulvescens . & non & Hurun Bay, Indonesia & 23 Dec 2003 & Fig. 2, E-F \\
\hline Cochlodinium convolutum & non & Imari Bay, West Japan & 18 Sep 2005 & Fig. 4, A-C \\
\hline Cochlodinium convolutum & non & Inokushi Bay, West Japan & 5 Nov 2002 & Fig. 4, D-F \\
\hline
\end{tabular}


Table 2. Taxonomic history of chain-forming species of the genus Cochlodinium.

\begin{tabular}{|c|c|c|c|c|}
\hline & C. catenatum & C. polykrikoides & C. heterolobatum & $\begin{array}{l}\text { Cochlodinium sp. type } \\
\text { Yatsushiro '78 }\end{array}$ \\
\hline NI011 & Illustrated as Pouchetia sp. in & & & \\
\hline Nakazawd 1911 & Tokyo Bay & & & \\
\hline Okamura 1916 & $\begin{array}{l}\text { Described as a new species, } C \text {. } \\
\text { catenatum in Tokyo Bay }\end{array}$ & & & \\
\hline Hirasaka 1922 & $\begin{array}{l}\text { Last records in Gokasho Bay } \\
\text { and Mikawa Bay }\end{array}$ & & & \\
\hline Kofoid \& Swezy 1921 & $\begin{array}{l}\text { Described as C. catenatum, but } \\
\text { different species }\end{array}$ & & & \\
\hline Margalef 1961 & & $\begin{array}{l}\text { Described as a new species in } \\
\text { Phosphorescence Bay }\end{array}$ & & \\
\hline Silva 1967 & & & $\begin{array}{l}\text { Described as a new species in } \\
\text { New Jersey }\end{array}$ & \\
\hline Kumada et al. 1980 & & & & $\begin{array}{l}\text { Reported as Cochlodinium sp. } \\
\text { type Yatsushiro ' } 78\end{array}$ \\
\hline Hargraves \& Víquez 1981 & $\begin{array}{l}\text { Recorded from Nicoya Bay, } \\
\text { Costa Rica }\end{array}$ & & & \\
\hline Yuki (pers. com.) & & $\begin{array}{l}\text { Observed in Gokasho Bay in } \\
1983\end{array}$ & & \\
\hline Yuki \& Yoshimatsu 1989 & & $\begin{array}{l}\text { Senior synonym for } C \text {. } \\
\text { heterolobatum and } \\
\text { Cochlodinium sp. type } \\
\text { Yatsushiro ' } 78\end{array}$ & & \\
\hline Vargas-Montero et al. 2004 & & $\begin{array}{l}\text { Recorded from Nicoya Bay, } \\
\text { Costa Rica as a new occurrence }\end{array}$ & & \\
\hline
\end{tabular}


Table 3. Morphological comparison of a single cell stage of four Cochlodinium species occurring around Japanese coastal waters.

\begin{tabular}{|c|c|c|c|c|}
\hline & C. catenatum & C. polykrikoides* & C. fulvescens & C. convolutum \\
\hline Length & Small $(24-27 \mu \mathrm{m})^{* *}$ & Small $(30-40 \mu \mathrm{m})^{* * *}$ & Intermediate $(45-50 \mu \mathrm{m}) * * *$ & Large $(60-70 \mu \mathrm{m})^{* * *}$ \\
\hline Cell shape & Subspherical to ovoidal & Ovoidal & Roundly ellipsoidal & Roundly subconical \\
\hline Pigmented body & $\begin{array}{l}\text { Present at the dorsal side of the } \\
\text { epicone }\end{array}$ & $\begin{array}{l}\text { Present at the dorsal side of the } \\
\text { epicone }\end{array}$ & $\begin{array}{l}\text { Present at the dorsal side of the } \\
\text { epicone }\end{array}$ & Absent \\
\hline Cingulum & Encircling 1.5 times of the cell & Encircling 1.8 to 2 times of the cell & Encircling ca. 2 times of the cell & Encircling 1.5 times of the cell \\
\hline Sulcus & & Running just below the cingulum & Running between the cingulum & \\
\hline Nucleus & $\begin{array}{l}\text { Spherical, at the anterior of the } \\
\text { epicone }\end{array}$ & $\begin{array}{l}\text { Spherical, at the anterior of the } \\
\text { epicone }\end{array}$ & $\begin{array}{l}\text { Spherical, at the anterior of the } \\
\text { epicone }\end{array}$ & Rectangular \\
\hline Chloroplasts & Rod-like & Rod-like & Granular & A few and light in color \\
\hline Cell-chain & Chain forming ( $>4$ cells) & Chain forming ( $>4$ cells) & Chain forming ( 4 cells) & Chain forming ( 2 cells) \\
\hline & & & & Hyaline cyst \\
\hline
\end{tabular}

* Cell length of the holotype given by Marglaef (1961) $50 \mu \mathrm{m}$

**Measuring chain-forming cells only because of no illustration of a single cell stage (Okamura, 1916).

$* * *$ Measuring cells in a single stage. 